\title{
Specific primers for Xanthomonas vesicatoria, a tomato bacterial spot causal agent
}

\author{
Edivânio R. Araújo • Marisa A. S. V. Ferreira • \\ Alice Maria Quezado-Duval
}

Accepted: 25 April 2013 / Published online: 10 May 2013

(C) KNPV 2013

\begin{abstract}
Xanthomonas vesicatoria is a member of the species complex associated with tomato bacterial spot. New and specific primers for $X$. vesicatoria were developed and validated. The primers were highly specific and detection was positive using purified bacterial DNA, bacterial suspensions and foliar lesions. These primers represent an additional tool for detection and identification of one of the species involved in this important disease complex.
\end{abstract}

Keywords Solanum lycopersicum $\cdot$ Xanthomonas vesicatoria $\cdot$ Molecular detection

Bacterial spot has a worldwide occurrence and causes serious economic losses (Jones et al. 1991). Xanthomonas vesicatoria is one of the species that compose the complex causing bacterial spot of tomato. Before the proposal of reclassification by Jones et al. (2004), the causal agents of the disease were classified as two distinct groups A and B, namely Xanthomonas axonopodis pv. vesicatoria and $X$. vesicatoria (Vauterin

E. R. Araújo • M. A. S. V. Ferreira

Departamento de Fitopatologia, Instituto de Biologia, Universidade de Brasília,

Brasília, DF, Brazil

E. R. Araújo · A. M. Quezado-Duval $(\bowtie)$

Laboratório de Fitopatologia, Embrapa Hortaliças,

Brasília, DF, Brazil

e-mail: alice.quezado@embrapa.br et al. 1995). Thus, the diversity within these two groups was still not well understood. Currently, four species are recognized as causal agents of tomato bacterial spot: $X$. vesicatoria, X. euvesicatoria, $X$. perforans, and $X$. gardneri (Jones et al. 2004). The most recent reports concerning $X$. vesicatoria were in the Russian Federation (Ignatov et al. 2009), the Indian Ocean region (Hamza et al. 2010), Tanzania (Mbega et al. 2012), and Brazil (Pereira et al. 2011; Costa et al. 2012). Xanthomonas campestris pv. raphani (Vicente et al. 2006), and X. arboricola (Mbega et al. 2012) may also be associated with lesions on tomato leaves, but biological and epidemiological aspects of these agents need to be better elucidated.

Specific primers are often used as molecular tools for the detection of various plant pathogens (RobèneSoustrade et al. 2010; López et al. 2012), including the tomato bacterial spot species complex (Koenraadt et al. 2009). However the genetic diversity of microorganisms can be generated and/or maintained by punctual deletions or insertions in the genome or by horizontal gene transfer (Arber 2000). Thus, to avoid false negatives in the identification process it is advisable to use more than one specific primer, whenever available. To overcome this constraint, primers designed to amplify conservative genome areas are being applied, such as the $\operatorname{gyr} B$ gene, which is rarely transmitted horizontally and is distributed ubiquitously among bacterial species (Kasai et al. 1998). This study aimed to develop specific primers from the partial DNA sequence of gyrB gene for Xanthomonas 
vesicatoria, and to validate them using a collection of $X$. vesicatoria from Brazil in assays with purified DNA, bacterial suspensions and symptomatic tomato leaves.

Fifteen strains of $X$. vesicatoria from three Brazilian regions (Midwest, Southeast and South) were used for the primers validation. The following strains were used as references: X. vesicatoria, IBSBF 2364 (Instituto
Biológico de Campinas, São Paulo=XV1111, from New Zealand); X. euvesicatoria, IBSBF 2363 (Instituto Biológico de Campinas, São Paulo $=$ Xvp197, from the USA), and EH 1996-212; X. perforans, IBSBF 2370 (Instituto Biológico de Campinas, São Paulo $=$ ATCC BAA-983, from the USA), and EH 2009-111; $X$. gardneri, IBSBF 2373 (Instituto Biológico de Campinas, São Paulo=XCGA2, from Yugoslavia), and
Table 1 DNA samples used in this study and Xv-gyrB-F/XvgyrB-R-based PCR assay specificity
+ , amplification; - no amplification

${ }^{a}$ Xanthomonas species reference strains associated with tomato bacterial spot, IBSBF 2363 originated from the USA, IBSBF 2364 from New Zealand, IBSBF 2370 from the USA and IBSBF 2373 from Yugoslavia

\begin{tabular}{|c|c|c|}
\hline DNA Samples & Host & PCR \\
\hline \multicolumn{3}{|l|}{ Xanthomonas vesicatoria } \\
\hline \multicolumn{3}{|l|}{ EH 1995-95; EH 1995-99; EH 1995-101; } \\
\hline \multicolumn{3}{|l|}{ EH 1994-102; EH 1995-103; EH 1995-104; } \\
\hline EH 1995-105; EH 1995-107; EH 1995-108; & Tomato & + \\
\hline \multicolumn{3}{|l|}{ EH 2009-42; EH 2010-08; EH 2010-24; } \\
\hline \multicolumn{3}{|l|}{ EH 2010-25; EH 2010-41; EH 2010-59; IBSBF 2364 } \\
\hline X. euvesicatoria & Tomato & - \\
\hline \multicolumn{3}{|l|}{ EH 1996-212; IBSBF $2363^{a}$} \\
\hline$X$. perforans & Tomato & - \\
\hline \multicolumn{3}{|l|}{ EH 2009-111; IBSBF $2370^{\text {a }}$} \\
\hline$X$. gardneri & Tomato & - \\
\hline \multicolumn{3}{|l|}{ EH 2010-64; IBSBF $2373^{a}$} \\
\hline X. raphani, IAPAR 11300; IBSBF 1590 & Brassica $\mathrm{sp}$. & - \\
\hline X. campestris pv. campestris, UnB 828 & Brassica sp. & - \\
\hline X. axonopodis pv. manihotis, UnB 1159 & Cassava & - \\
\hline$X$. campestris pv. vitians, UnB 110; UnB 830 & Lettuce & - \\
\hline$X$. citri pv. anacardii, IBSBF 2579 & Cashew & - \\
\hline X. campestris pv. armoraciae, IBSBF 1102 & Iberis sp. & - \\
\hline X. campestris pv. viticola, UnB 1318 & Grape & - \\
\hline$X$. citri pv. mangiferaeindicae, IBSBF 2586 & Mango & - \\
\hline Pseudomonas marginalis, IBSBF 1240 & Tomato & - \\
\hline P. cichorii, IBSBF 402; IBSBF 1748 & Tomato & - \\
\hline P. syringae pv. syringae, IBSBF 451; IBSBF 375; IBSBF 281 & Tomato/Lilac & - \\
\hline P. syringae pv. tomato, IBSBF 836; IBSBF 432; EH 75 & Tomato & - \\
\hline Pseudomonas viridiflava, IBSBF 1464 & Tomato & - \\
\hline Clavibacter michiganensis subsp. michiganensis, UnB 1151 & Tomato & - \\
\hline Ralstonia solanacearum, UnB 1273 & Tomato & - \\
\hline Acidovorax avenae subsp. citrulli, 646-2 & Melon & - \\
\hline Erwinia chrysanthemi, UnB 336 & Chard & - \\
\hline Erwinia psidii, IBSBF 1347; IBSBF 453 & Guava & - \\
\hline Pectobacterium carotovorum subsp. carotovorum, IBSBF 776 & Tomato & - \\
\hline Alternaria solani, IBSBF 1940 & Tomato & - \\
\hline Corynespora cassiicola, IBSBF 1828 & Tomato & - \\
\hline Stemphylium sp., EH 502 & Tomato & - \\
\hline Unknown epiphytic and/or endophytic bacteria (10) & Tomato & - \\
\hline DNA tomato & - & - \\
\hline
\end{tabular}


EH 2010-64. These strains are maintained in the work collection of the Laboratory of Plant Pathology of the Brazilian Vegetable Research Center (Embrapa Hortaliças), Brasília, DF, Brazil. Brazilian isolates were identified by: i) cultural characteristics in NA - nutrient agar medium (Schaad et al. 2001), ii) comparison of genomic profiles generated by BOX-PCR (Versalovic et al. 1991) with reference strain IBSBF 2364, and iii) pathogenicity tests on tomato (var. Yuba). Additionally, in order to attest the specificity of the new primers, 32 bacterial and fungal strains pathogenic to tomato or other hosts, from different collections (Embrapa Hortaliças EH; Instituto Agronômico do Paraná - IAPAR, Instituto Biológico de Campinas - IBSBF and Universidade de Brasília - UnB), and 10 bacterial isolates representative of epiphytic and/or endophytic populations on tomato leaves were used (Table 1). Finally, the primers were evaluated with the DNA of tomato plants (vars. Floradade and Ponderosa).

DNA extraction was performed according to Wilson (1999) and/or Mahuku (2004). DNA samples were diluted up to the approximately concentration of $50 \mathrm{ng} / \mu \mathrm{l}$ and kept at $-20{ }^{\circ} \mathrm{C}$ until used. For amplification reactions with bacterial suspensions, we recovered the colonies grown on NA for $48 \mathrm{~h}$ at $28{ }^{\circ} \mathrm{C}$. Bacterial suspensions were prepared in sterile distilled water, and its concentration was adjusted in spectrophotometer $\left(\mathrm{OD}_{600}=0.3\right)$ to approximately $5 \times$ $10^{8} \mathrm{CFU} / \mathrm{ml}$ (Jones et al. 2000). We used both purified DNA and bacterial suspensions $(2 \mu \mathrm{l})$ for PCR reaction.

The primers were designed with Primer-BLAST Primer designing tool (http://www.ncbi.nlm.nih.gov), to amplify a 104-bp fragment from the partial sequence of the gyrase beta subunit ( $g y r B$ ) gene of strain LMG 920 of $X$. vesicatoria, available at GenBank (access number EU015399.1). By using BLAST bases similarity (http:// www.ncbi.nlm.nih.gov), $100 \%$ query cover was obtained only for $X$. vesicatoria strains. The oligonucleotide sequences were: $\mathrm{Xv}$-gyrB-F (5'-ATACGCGT TGGGCGAGCCT-3') and Xv-gyrB-R (5' CATCGCTGAAGATGGCCACG GCT-3'). PCR was performed in a thermocycler My Cycler ${ }^{\mathrm{TM}}$ (BIO RAD) with the following program: $95^{\circ} \mathrm{C}$ for $4 \mathrm{~min}$ followed by 30 cycles of $95{ }^{\circ} \mathrm{C}$ for $30 \mathrm{~s}, 68{ }^{\circ} \mathrm{C}$ for $30 \mathrm{~s}, 72{ }^{\circ} \mathrm{C}$ for $30 \mathrm{~s}$, and a final extension at $72{ }^{\circ} \mathrm{C}$ for $3 \mathrm{~min}$. The reactions consisted of: $1.62 \mathrm{mM}$ of $\mathrm{MgCl}_{2}$; $0.2 \mathrm{mM}$ of each dNTPs; $1 \mu \mathrm{M}$ of each primer; $1.26 \mathrm{U}$ of $\mathrm{Taq}$ DNA polymerase; approximately $50 \mathrm{ng} / \mu \mathrm{l}$ of DNA; and Milli-Q ${ }^{\circledR}$ water to a final volume of $12 \mu \mathrm{l}$.

PCR products were analyzed by agarose gel $(1.5 \%)$ electrophoresis in $0.5 \mathrm{X}$ TBE buffer conducted at $5 \mathrm{~V} / \mathrm{cm}$ for $2 \mathrm{~h}$ and scanned using the imaging system L-PIX ST (Loccus Biotecnologia, São Paulo, Brazil).

Bacterial suspensions $\left(\approx 5 \times 10^{8} \mathrm{CFU} / \mathrm{ml}\right)$ were prepared in magnesium sulphate solution $(10 \mathrm{mM})$ and homogeneously sprayed over leaf surfaces (two plants
Fig. 1 Specificity of $\mathrm{Xv}$ gyrB-F/Xv-gyrB-R-based PCR assay for the detection of Xanthomonas vesicatoria in A: purified DNA $(\approx$ $50 \mu \mathrm{l} / \mathrm{ml})$; B: Bacterial suspension $\left(\approx 5 \times 10^{8} \mathrm{CFU} / \mathrm{ml}\right)$; $\mathrm{C}$ : Symptomatic leaves of tomato. PC: Positive control (IBSBF 2364); CE: Crude extract of symptomatic leaves of tomato; 1:10: 10fold dilution of the crude extract of symptomatic leaves; 1:100: 100-fold dilution of the crude extract of symptomatic leaves; NI: Uninoculated leaves; $\mathrm{NC}$ : Negative control; M: molecular marker (100 bp DNA Ladder, Invitrogen)

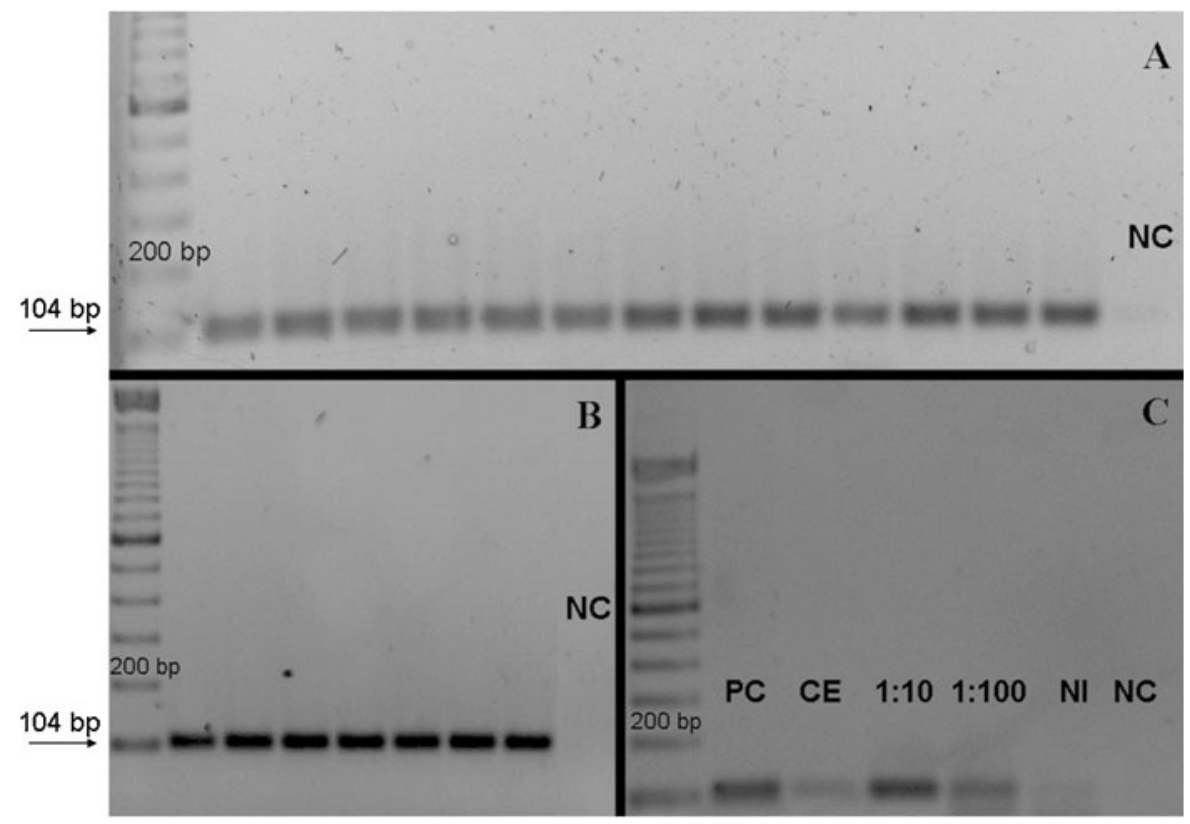


with strain EH 2010-25) up to the run-off point. Plants were then incubated for $48 \mathrm{~h}$ in moist chambers consisting of plastic bags previously moistened with tap water. After symptom development, a circular section with a diameter of $10 \mathrm{~mm}$ contained one individual leaf spot was macerated in $200 \mu$ l of distilled sterilized water 10 days after the inoculation. For PCR reaction, $2 \mu \mathrm{l}$ of the undiluted leaf crude extract and its dilutions of 1:10 and 1:100 were used. The visualization of the fragments was as previously described. For all assays, each reaction was performed at least twice.

The primers were specific, amplifying the purified DNA and bacterial suspensions of all strains of $X$. vesicatoria used (Fig. 1) but not DNA from the other species associated with tomato bacterial spot (Table 1). Similarly, there was no DNA amplification from other plant pathogens tested, or from tomato leaves.

The development of specific primers for Xanthomonas species associated with tomato bacterial spot has been reported in some studies. All four species can be identified and distinguished by the primers designed by Koenraadt et al. (2009). Xanthomonas perforans can be identified indirectly with primers (RST 88/89) developed by AstuaMonge et al. (2000) to amplify avirulence gene $a v r X v 3$. In the same way, X. euvesicatoria can be identified indirectly with primers (RST 27/28) designed by Bouzar et al. (1994) to amplify the gene $a v r R x v$ and also with specific primers (Xeu2.4/Xeu2.5) developed by Moretti et al. (2009). For Xanthomonas vesicatoria, besides the pair specific primers of Koenraadt et al. (2009), new specific primers were designed by Beran and Mráz (2013). These primers were developed from partial DNA sequences of $a t p D$, and were validated with purified bacterial DNA. Primers Xv-gyrB-F/Xv-gyrB-R, here reported, are an additional tool for confirming $X$. vesicatoria identification, that can be also used for direct detection of the pathogen on its host tissue were, speeding up the process of diagnosis (Fig. 1).

The crude extracts samples inhibited PCR, but from a 1:10 dilution it was possible to detect the pathogen through a positive PCR signal. Inhibition of PCR when using crude extracts as templates is often observed because plant polyphenols can form complexes with nucleic acids (Koonjul et al. 1999). The studies of Moretti et al. (2009) for X. euvesicatoria, and of Araújo et al. (2012), for the four tomato bacterial spot Xanthomonas have also shown the applicability of specific primers directly in symptomatic plants.
The primers developed in this study need to be further evaluated for their sensitivity and reproducibility for routine use. However, their specificity for $X$. vesicatoria and a detection limit that allows the amplification of the pathogens DNA in a diluted crude extract from a lesion, reveal their potential to be also used in diagnostic assays with infected seeds and seedlings.

\section{References}

Araújo, E. R., Costa, J. R., Ferreira, M. A. S. V., \& QuezadoDuval, A. M. (2012). Simultaneous detection and identification of the Xanthomonas species complex associated with tomato bacterial spot using species-specific primers and multiplex PCR. Journal of Applied Microbiology, 113, 1479-1490.

Arber, W. (2000). Genetic variation: molecular mechanism and impact on microbial evolution. FESM Microbiology Review, 24, 1-7.

Astua-Monge, G., Minsavage, G. V., Stall, R. E., Davis, M. J., Bonas, U., \& Jones, J. B. (2000). Resistance of tomato and pepper to T3 strains of Xanthomonas campestris pv. vesicatoria is specified by a plant inducible avirulence gene. Molecular Plant-Microbe Interactions, 13, 911-921.

Beran, P., \& Mráz, I. (2013). Species-specific PCR primers for detection of Xanthomonas vesicatoria. Crop Protection, 43, 213-215.

Bouzar, H., Jones, J. B., Minsavage, G. V., Stall, R. E., \& Scott, J. W. (1994). Proteins unique to phenotypically distinct groups of Xanthomonas campestris pv. vesicatoria revealed by silver staining. Phytopathology, 84, 39-44.

Costa, J. R., Araújo, E. R., Becker, W. F., Ferreira, M. A. S. V., \& Quezado-Duval, A. M. (2012). Ocorrência e caracterização do complexo de espécies causadoras da mancha bacteriana do tomateiro no Alto Vale do Rio do Peixe, SC. Tropical Plant Pathology, 37, 149-154.

Hamza, A. A., Robène-Soustrade, I., Jouen, E., Gagnevin, L., Lefeuvre, P., Chiroleu, F., et al. (2010). Genetic and pathological diversity among Xanthomonas strains responsible for bacterial spot on tomato and pepper in the southwest Indian Ocean region. Plant Disease, 94, 993-999.

Ignatov, A. N., Kornev, K. P., Matveeva, E. V., Pekhtereva, E. S., Polityko, V. A., Budenkov, N. I., et al. (2009). Occurrence of bacterial spot and bacterial canker of tomato in the Russian Federation. Acta Horticulturae, 808, 247-249.

Jones, J. B., Jones, J. P., Stall, R. E., \& Zitter, T. A. (1991). Compendium of tomato diseases. St Paul: APS Press. 73 p.

Jones, J. B., Bouzar, H., Stall, R. E., Almira, E. C., Roberts, P. D., Bowen, B. W., et al. (2000). Systematic analysis of xanthomonads (Xanthomonas spp.) associated with pepper and tomato lesions. International Journal of Systematic and Evolutionary Microbiology, 50, 1211-1219.

Jones, J. B., Lacy, G. H., Bouzar, H., Stall, R. E., \& Schaad, N. W. (2004). Reclassification of the xanthomonads associated with 
bacterial spot disease of tomato and pepper. Systematic and Applied Microbiology, 27, 755-762.

Kasai, H., Watanabe, K., Gasteiger, E., Bairoch, A., Isono, K., Yamamoto, S., et al. (1998). Construction of the gyrB database for the identification and classification of bacteria. Genome Informatics Ser. Workshop on Genome Informatics, 9, 13-21.

Koenraadt, H., van Betteray, B., Germain, R., Hiddink, G., Jones, J. B., Oosterhof, J., et al. (2009). Development of specific primers for the molecular detection of bacterial spot of pepper and tomato. Acta Horticulturae, 808, 99-102.

Koonjul, P., Brandt, W. F., Farrant, J. M., \& Lindsey, G. G. (1999). Inclusion of polyvinylpyrrolidone in the polymerase chain reaction reverses the inhibitory effects of polyphenolic contamination of RNA. Nucleic Acids Research, 27, 915-916.

López, M. M., Peñalver, J., Morente, M. C., Quesada, J. M., Navarro, I., López-Soriano, P., et al. (2012). Evaluation of the efficiency of a conventional PCR protocol for the diagnosis of bacterial spot disease caused by Xanthomonas arboricola pv. pruni in stone fruits and almond. Journal of Plant Pathology, 94(Suppl. 1), S1.75-S1.82.

Mahuku, G. S. (2004). A simple extraction method suitable for PCR-based analysis of plant, fungal, and bacterial DNA. Plant Molecular Biology Reporter, 22, 71-81.

Mbega, E. R., Mabagala, R. B., Adriko, J., Lund, O. S., Wulff, E. G., \& Mortensen, C. N. (2012). Five species of xanthomonads associated with bacterial leaf spot symptoms in tomato from Tanzania. Plant Disease, 96, 760.

Moretti, C., Amatulli, M. T., \& Buonaurio, R. (2009). PCR-based assay for the detection of Xanthomonas euvesicatoria causing pepper and tomato bacterial spot. Letters in Applied Microbiology, 49, 466-471.

Pereira, R. C., Araújo, E. R., Ferreira, M. A. S. V., \& QuezadoDuval, A. M. (2011). Occurrence of Xanthomonas species causing bacterial spot in fresh market tomato fields in Brazil. Acta Horticulturae, 914, 61-64.

Robène-Soustrade, I., Legrand, D., Gagnevin, L., Chiroleu, F., Laurent, A., \& Pruvost, O. (2010). Multiplex nested PCR for detection of Xanthomonas axonopodis pv. allii from onion seeds. Applied and Environmental Microbiology, 76, 26972703.

Schaad, N. W., Jones, J. B., \& Chun, W. (2001). Laboratory guide for identification of plant pathogenic bacteria. St Paul: American Phytopathological Society Press.

Vauterin, L., Hoste, B., Kersters, K., \& Swings, J. (1995). Reclassification of Xanthomonas. International Journal of Systematic Bacteriology, 45, 472-489.

Versalovic, J., Koeuth, T., \& Lupski, J. R. (1991). Distribution of repetitive DNA sequences in eubacteria and application to fingerprinting of bacterial genomes. Nucleic Acids Research, 19, 6823-6831.

Vicente, J. G., Everett, B., \& Roberts, S. J. (2006). Identification of isolates that cause a leaf spot disease of brassicas as Xanthomonas campestris pv. raphani and pathogenic and genetic comparison with related pathovars. Phytopathology, 96, 735-745.

Wilson, K. (1999). Preparation of genomic bacteria. In F. M. Ausubel, R. Brent, R. E. Kingston, D. D. Moore, J. G. Seidman, J. A. Smith, \& K. Struhl (Eds.), Short protocols in molecular biology (pp. 2-14). New York: John Wiley. 